\title{
Returning to Yahweh and Yahweh's Return: Aspects of שוּב in the Book of Malachi
}

\author{
BLESSING ONORIODE BOLOJE \\ (University of Pretoria, South Africa)
}

\begin{abstract}
This article examines aspects of שוּב in the book of Malachi against the background of an obvious complementary and inadequate pattern of Israel/Judah's repentance and incomplete restoration. As people whose history is characterised by covenant failure and refusal to repent, the book of Malachi present a robust conglomeration of persistent noncompliance and rebellion of the postexilic Yehudite community, thus making her guilty of unfaithfulness and unworthy of Yahweh's restoration. The article surveys aspects of שוּ in three relative books of the Book of the Twelve and then examines three seemingly connected aspects; namely, Torah compliance, return to the right cult and Yahweh's return in the book of Malachi. What emerges at the end of this article is that Israel/Judah's hope of spiritual revitalisation, and complete restoration, is her faithful and wholehearted return to the right cult and to Yahweh's Torah.
\end{abstract}

KEYWORDS: Book of the Twelve, Malachi, שוב, cult, Yahweh's Torah, restoration

\section{A INTRODUCTION}

The Book of the Twelve is considered to be complete in its structure, plot and genre. In line with the MT sequence of these books, Paul R. House underscores a consistent structure of sin, punishment and restoration which lies at the heart of the Book of the Twelve and reflects its plot and literary genre. ${ }^{1}$ Interestingly, in his theological construct and formulation, House observes that the books of Hosea and Joel bring together Israel's sins and the nations that continued in sin

* Submitted: 23/01/2020; peer-reviewed: 03/03/2020; accepted: 05/03/2020. Blessing Onoriode Boloje, "Returning to Yahweh and Yahweh's Return: Aspects of שוּ in the Book of Malachi”, Old Testament Essays 33 no. 1 (2020): 143 - 161. DOI: https://doi.org/10.17159/2312-3621/2020/v33n1a9.

1 Paul R. House, The Unity of the Twelve (JSOTSup 97; Sheffield: Almond Press, 1990), 68. Marvin A Sweeney analyses the sequence of the first six writings of the Twelve in the two collections of the MT and LXX. He observes that although not universal, there is the existence of substantial evidence which situates the MT as reflecting the original arrangement of the books. Marvin A. Sweeney, "Sequence and Interpretation in the Book of the Twelve," in Reading and Hearing the Book of the Twelve (eds., James D. Nogalski and Marvin A. Sweeney, SBLSymS 15; Atlanta: Society of Biblical Literature, 2000), 56, 62-64. 
until they reached the peak of judgement, which serves as a medium of cleansing. Judgement for House is found in Nahum and Habakkuk and the process of restoration which begins in Zephaniah reaches its climax in the book of Malachi. ${ }^{2}$ In a wide array of scholarly monographs and essays on the Book of the Twelve, several related and frequent motifs, and themes have been considered with the dominant ones being the Day of Yahweh, productiveness of the land, the destiny of God's people, and the problem of evil (i.e., theodicy). ${ }^{3}$ In view of Israel's covenant relationship with Yahweh, which is characterised by failure and refusal to repent, this article, focuses on aspects of (turning/returning) in the book of Malachi.

The book of Malachi ${ }^{4}$ has been acknowledged by scholars as possessing artistic brilliance and merit. ${ }^{5}$ Its style is simple and clear, direct and forceful, with little demand upon imagination of the readers. John Smith remarks that, "The figurative element is very limited; but such figures as are employed are fresh and suggestive." Several discussions regarding the book of Malachi focus on its literary character and historical setting, and its classification as a series of disputation. ${ }^{7}$ However, it is evident that Malachi's theological message is highly robust and imaginative much more than its form-critical readers have proposed.

2 House, The Unity of the Twelve, 111-160.

3 James D. Nogalski, "Recurring Themes in the Book of the Twelve: Creating Points of Contact for a Theological Reading," Int 61(2007):125; Paul L. Redditt, "Themes in Haggai-Zechariah-Malachi," Int 61(2007):184,188-195. See also Terence Collins, who recognizes an abundance of themes such as covenant/election, fertility/infertility, faithfulness/unfaithfulness, turning/returning, justice/mercy of God, God's kingship, Temple/Mount Zion as Yahweh's dwelling place, the nations as adversaries and associates. Terence Collins, "The Scroll of the Twelve," in The Mantle of Elijah: The Redaction Criticism of the Prophetic Books (The Biblical Seminar 20; Sheffield: Sheffield Academic Press, 1993), 65.

4 For lack of space and scope, this article does not focus on discussion on issues of authorship, date, a redactional and compositional history of the book of Malachi. For a highlight on these issues, see Elie Assis, "Structure and Meaning in the Book of Malachi," in Prophecy and the Prophets in Ancient Israel: Proceedings of the Oxford Old Testament Seminar (ed., John Day, LHBOTS 531; New York: T \& T Clark, 2010), 354-369.

5 John Merlin Smith, A Critical and Exegetical Commentary on the Book of Malachi (New York: T \&T Clark, 1912), 4. Scholars like Carl Friedrich Keil and Franz Delitzsch believe that Malachi does not measure up to earlier prophetic writings and his messages were more sermonic. However, they hold that Malachi's message is still vigorous, pure and beautiful. Carl Friedrich Keil and Franz Delitzsch, The Minor Prophets, vol. 2 (trans., James Martin; Grand Rapids, MI: Eerdmans, 1949), 428-29.

6 Smith, A Critical and Exegetical Commentary on the Book of Malachi, 4.

7 R. Michael Fox, A Message from the Great King: Reading Malachi in Light of Ancient Persian Royal Messenger Texts from the Time of Xerxes (LTHS 17; Winona Lake, Indiana: Eisenbrauns, 2015), 3. 
In keeping with long-standing and older prophetic traditions, Malachi constructed a robust theology of the theme of return as an incontrovertible and unifying aspect of the Book of the Twelve. In this article the writer examines aspects of the theme of return (שוב) in the Book of the Twelve, ${ }^{8}$ and then three seemingly connected aspects of שוב; namely, Torah compliance, return to the right cult and Yahweh's return in the book of Malachi.

\section{B ASPECTS OF שיוּ IN THE BOOK OF THE TWELVE}

As already noted, the Book of the Twelve is connected with diversity of themes, and it is difficult to state very precisely, what the redactors and/or editors of the books want readers to consider as most significant. ${ }^{9}$ Whilst several studies have been done in light of the literary unity of the Book of the Twelve, the theme of return (שיב) is given considerable attention in the Book of the Twelve. The Hebrew word שוּב which expresses the idea of return (repentance) ${ }^{10}$ in the

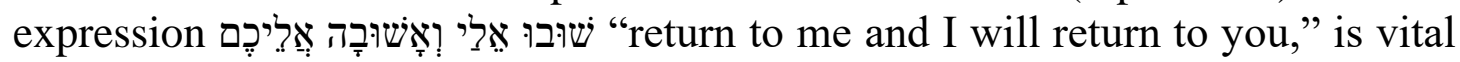
to the unfolding of the unity of the Twelve, but at the same time, allows them to preserve their individual uniqueness. ${ }^{11}$

Interestingly, the Book of the Twelve opens and closes with the idea of

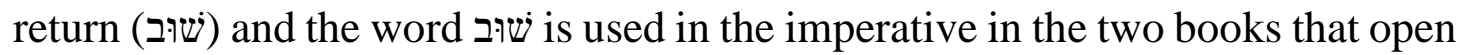
(Hos 14:2, 3 MT, 14:1,2 ET; Joel 2:12,13) and close (Zech 1:3,4; 9:12; Mal 3:7) the Twelve. ${ }^{12}$ The purpose of this section is simply to trace the idea of return (שיוּ), which finds expression in the imperative exhortation of the prophets to their addresses. The imperative exhortation to return in my submission is an

8 Although שוּב is mentioned in other canonical books of the Book of the Twelve, I have limited attention to the opening and final books in which שוּב is found in the specific expression, "Return to me and I will return to you" (Hos 14:1-4 [ET 14:2-5]; Joel 2:12-14; and Zech 1:6).

9 Jason T. LeCureux, The Thematic Unity of the Book of the Twelve (HBM 41; Sheffield: Sheffield Phoenix, 2012), 16; cf. Collins, "The Scroll of the Twelve," 65.

10 The Hebrew word שוּב which is translated in certain contemporary theological contexts as "repent" means "turn around." The call to "turn around" or "repent" implies a change of attitude, involving a public show of repentance and thus walking in the ways of Yahweh. James D. Nogalski, The Book of the Twelve: Micah-Malachi (Macon, Georgia: Smyth \& Helwys Publishing, Inc., 2011), 826.

11 LeCureux, The Thematic Unity of the Book of the Twelve, 2.

12 The MT of the Book of the Twelve has been widely recognized in the ordering of its various compositions. The MT collections are ordered this manner: Hosea, Joel, Amos, Obadiah, Jonah, Micah, Nahum, Habakkuk, Zephaniah, Haggai, Zechariah, and Malachi. See Marvin A. Sweeney, "Synchronic and Diachronic Concerns in Reading the Book of the Twelve Prophets," in Perspectives on the Formation of the Book of the Twelve (eds., Rainer Albertz, James Nogalski, Jacob Wöhrle, BZAW 433; New York: Walter de Gruyter, 2012), 25; LeCureux, The Thematic Unity of the Book of the Twelve, 22. 
essential theological thrust that places significance on the meaning and shape of their work. Because the limited scope of this study will not allow a detailed analysis of the use of return (שיב) in every book of the Twelve, in this section, the motif of return (שיב) is examined briefly in the books of Hosea, Joel and Zechariah. This is not to deny the supportive role ששוּב plays in the other prophetic books of the Twelve but to simply use this as a basis for developing the theme of return in the book of Malachi. ${ }^{13}$

\section{2 in the book of Hosea}

In the Book of the Twelve, the exhortation to return (שוּב) first finds expression in the book of Hosea. As a narrative history and prophetic oracle, the book's introduction places Hosea's ministry within the context of the eighth century BCE. ${ }^{14}$ This was a period of historic and dramatic development for the dual kingdoms of Israel and Judah as well as for the surrounding nations of the ancient Near East. It was a time of active oppression of the poor in slavery and of the worshipping of idols. ${ }^{15}$ The book gives a graphic description of Israel's spiritual adultery, and Yahweh's boundless love for His sinful people. Because of Yahweh's sustaining grace, he offered Israel an opportunity to repent and turn to Him. The narrative itself is arranged in chiastic structure, and around the marriage theme which is closely connected to that of the covenant. Although they have been redeemed by God and brought into a covenant relationship with Him $(11: 4 ; 12: 9 ; 13: 4)$, they have violated that covenant repeatedly (e.g., 6:7; $8: 11-14)$. On account of Israel's violation of her fidelity to God and His covenant with them, they needed repentance $(2: 14 ; 3: 5 ; 5: 6 ; 6: 6-7 ; 7: 8-10 ; 14: 4)$ as well as practicing righteousness $(10: 12 ; 12: 6 ; 14: 9)$. The theme of violation of covenant and the need of repentance are closely associated with that of judgment (e.g., 3:4; 4:7-13, 15-18; 5:11; 8:4-6; 9:1; 10:5, 8; 11:2, 7;13:2;14:8). ${ }^{16}$

13 For discussions on the use of return (שיוּ) in the Book of the Twelve outside these three prophetic books, see LeCureux, The Thematic Unity of the Book of the Twelve, 131-171.

14 Robert B. Chisholm, Jr., Interpreting the Minor Prophets (Grand Rapids: Zondervan, 1990), 21. It is suggested that Hosea began his ministry at a relatively young age and that his ministry may have lasted until about 710 BCE. See Duane A. Garrett, Hosea, Joel: New American Commentary (Nashville: Broadman \& Holman, 1997), 22. 15 See Walter C. Kaiser, Jr., A History of Israel (Nashville: Broadman \& Holman, 1998), 352. Relative information regarding the Northern Kingdom's reinvigorated economy may be found in the well-known Samaria Ostraca. For further details, see Alfred J. Hoerth, Archaeology and the Old Testament (Grand Rapids:Baker 1998), 329-330; Willem A. VanGemeren, Interpreting the Prophetic Word (Grand Rapids: Zondervan, 1990), 106.

16 Rick Johnson, "Hosea 4-10: Pictures at an Exhibition," SJT 36 (1993): 20. See further Francis Landy, "In the Wilderness of Speech: Problems of Metaphor in Hosea," BibInt 3 (1995): 35-39. 
Using a gender matrix, the book of Hosea begins with the portrayal of the prophet's marriage to Gomer and her idolatry.17 As a fitting introduction to the Book of the Twelve, Hosea's understanding of Israel's history makes the motif of return significant and serves as a bridge between eighth-century, pre-exilic Israel and fifth-century, postexilic Judah.18 In his analysis of the use of in the Hosea, LeCureux notes that in all of its 24 occurrences, שוּב appears in three broad categories: punishment, restoration and repentance. In the category of as punishment, three sub-categories are delineated. First is the idea of recompense, which bears the seal of Yahweh's relative response to the failures of Israel actions $(4: 9 ; 12: 3$, ET 12:2; 12:15, ET 12:14). A second follow up to the idea of the punishment motif of שוּב closely related to Yahweh's displeasure with Israel over her pact with other nations. The implication of this is the enforcement of the covenant curses of Deuteronomy 28 and the reversal of the Exodus: "Now will he remember their iniquities, and will take vengeance on their sins: they have returned (יזשוּבוּ: Egypt, and they shall eat unclean things among the Assyrians" (Hos 8:13b; cf. $9: 3 ; 11: 5)$. The third reference to the idea of שוּ a punishment (that is, miscellaneous punishment) is in 2:11 and 5:15. In these two verses, Yahweh's actions are a response to Israel's sins:

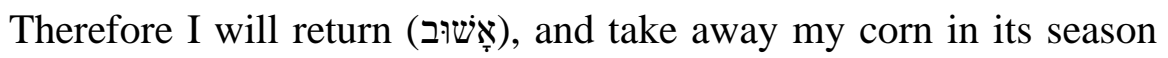
and my wine in its time; and I will take away my raiment and my linen clothes, so that she shall not cover her nakedness (2:11, ET 2:9).

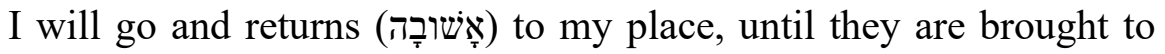
naught, and then shall they seek my face $(5: 15)$.

The restorative exhortation of שוּב is found in $3: 5 ; 6: 11 b ; 11: 9 ;$ and14:5, 8, where it underscores the necessity of Israel's returning to Yahweh in repentance and the resulting implications of Yahweh's response to their return. שוּב as repentance receives further categorisation such as refusal to repent $(5: 4$; $7: 10,16 ; 11: 5)$, reluctant repentance $(2: 9)$, and a call to repentance $(6: 1 ; 12: 7$; 14:2, 3). ${ }^{19}$ The fulcrum of the motif of in Hosea on the one hand is either the return of the people to Yahweh in covenant fidelity, so as to receive the good fortune associated with the covenant, or the turning away of the people from Yahweh to form a political alliance with other nations. This was a step into cultic idolatry, and consequently resulted to the experience of the tragedies of covenant violation. On the other hand, Yahweh will return to His people in the form of grace (restoration of fortune) or judgment. On both sides, there is openendedness to this struggle; while the people face the struggle over sin to return

17 Paul L. Redditt, "The Production and Reading of the Book of the Twelve," in Reading and Hearing the Book of the Twelve; SBLSymS 15 (eds., James D. Nogalski and Marvin A. Sweeney; Atlanta: Society of Biblical Literature, 2000), 18.

18 LeCureux, The Thematic Unity of the Book of the Twelve, 100.

19 LeCureux, The Thematic Unity of the Book of the Twelve, 64. 
to Yahweh, Yahweh struggles to maintain His holiness and commitment to love Israel. ${ }^{20}$ In Hosea, the important thing to note is that Israel's return is grounded in Yahweh's mercy (14:4b; cf. Deut 4:31), and essentially consists of obedience to Yahweh's commandments $(13: 4 ; 10)$. The imperative exhortation to return (שוּ) to Yahweh can only be possible if the people (Israel) wholeheartedly put an end to their alliance with other nations. ${ }^{21}$ Hosea thus leaves open the call to return for readers of the Book of the Twelve. The possibility of an anticipated

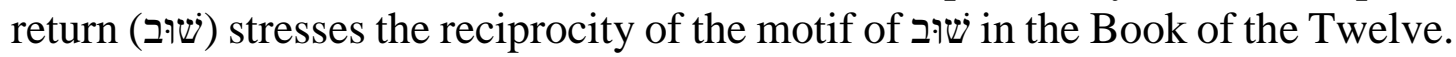

\section{2. $\quad$ in the book of Joel}

The book of Joel opens with a situation that shows that the land of Israel/Judah was in complete devastation and desolation, thus necessitating a call to repentance. Joel's call to return (שוּב) begins with a lengthy exhortation to repentance (2:12-17), in the manner that Hosea ends $(14: 2-3)$, and culminates with an eschatological depiction of Yahweh's judgment on the nations. This is not unconnected with the theme of the Day of Yahweh. The Day of Yahweh is a decisive moment in which Yahweh will intervene in history. References to the Day of Yahweh, however, have to be accessed within the context of the scope of time, the targets, and Yahweh's mode of operation. With respect to Joel, the time may be looming, requiring urgent response $(2: 1-11,12-17)$, or remote, thus inspiring the hope of positive development in the interval (4:1-21, ET 3:1-21). The target may be the people of Yahweh (Judah, Jerusalem, Israel, or Samaria) or other nations (Edom, Assyria, Babylon), ${ }^{22}$ and the mode of Yahweh's operation on this Day may be His role as a Judge (3:1-8), or as the commander of the host of heaven $(2: 1-11)$. In both narrative framework of the imperative exhortation to return (שיוּ), together with the accompanying promises (Hos 14:47 and Joel 2:18-25), there is no record of a corresponding evidence of repentance from the people who are faced with devastation and destruction. In all, the possibility of Yahweh granting them the promised blessings is dependent upon their positive response, a response that is never reported in the texts. ${ }^{23}$

\footnotetext{
20 LeCureux, The Thematic Unity of the Book of the Twelve, 64.

21 Daniel C. Timmer, The Non-Israelite Nations in the Book of the Twelve: Thematic Coherence and the Diachronic-Synchronic Relationship in the Minor Prophets (BIS 135; Leiden: Brill, 2015), 28.

22 Both Joel and Obadiah are closely connected with neighbouring writings by linguistic and thematic features. Nogalski notes that, "The intricacy of the connections of Joel and Obadiah to their contexts suggests that their final form owes much to their literary locations in the Book of the Twelve." Nogalski, The Book of the Twelve: MicahMalachi, 495-496.

23 Nogalski, The Book of the Twelve: Micah-Malachi, 501; LeCureux, The Thematic Unity of the Book of the Twelve, 126.
} 


\section{3. $\quad$ in the book of Zechariah}

Although it is difficult to interpret, ${ }^{24}$ the book of Zechariah makes significant contribution to the motif of return (שיב) not only in the development of Zechariah's message but also to the overall message of the Book of the Twelve. In Zechariah, the motif of return (שיוּ) is connected with the meaning of the prophet's name (Zechariah: Yahweh has remembered) and recounts the message of Haggai's temple vision of the universal sovereignty of Yahweh. ${ }^{25}$ The literary portrayal of Zechariah 1-8 introduces the prophet as someone who confronts the people of his generation to return (שיבוּ (שיכ) to Yahweh (1:2-6). ${ }^{26}$ The call is to return

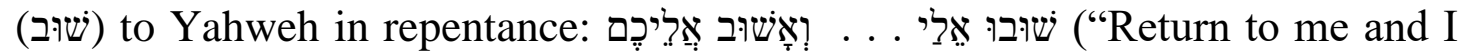
will return to you"), and it is accentuated twice with the prophetic formulae: אֵָ ("Thus says the LORD") (1:3). This call, which builds on the proceeding verse, indicates that the previous generation maintained a history of rebellion even with the persistent call to repentance from formal prophets (1:4). Employing several rhetorical questions, Zechariah challenges the current generation not to repeat the mistakes of the past. Thus, the call to return (שיוּ) offers the current generation an opportunity to change the situation that has gained control of them since the destruction of Jerusalem. Interestingly, Zechariah 1:6 concludes with a return to the voice of the narrator: "they returned

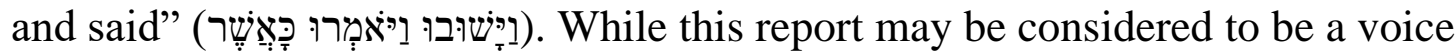
of the previous generation, the reference to "they" in this report fits well Zechariah's present generation. As Nogalski notes, "Moreover, this positive response of the people also fits with the flow of Haggai and Zechariah, where the people gradually appear to buy into constructing the temple more as Haggai unfolds." 27

Zechariah also associates שוּ שith Yahweh's restoration of Jerusalem along with the return of Yahweh's glory to Zion and Jerusalem (2:6-9, 10-12;

24 For a reading of the complex issues of redational composition, dating and interpretation of Zechariah. See Paul L. Redditt, "Nehemiah's First Mission and the Date of Zechariah 9-14," CBQ 56 (1994): 675-677; Paul L. Redditt, Haggai, Zechariah and Malachi (NCBC; Grand Rapids: Eerdmans: 1995), 97-100; David L. Petersen, Zechariah 9-14 and Malachi: A Commentary (Louisville: Westminster John Knox, 1995), 137-39; Mark J. Boda, "From Fasts to Feasts: The Literary Function of Zechariah 7-8," CBQ 65 (2003): 390-407; Serge Frolov, "Is the Narrator also Among the Prophets? Reading Zechariah without Presuppositions," BibInt 13 (2005): 13-40; Jacob Wöhrle, "The Formation and Intention of the Haggai-Zechariah Corpus," JHS 6/10 (2006): 1-14; Byron G. Curtis, Up the Steep and Stony Road: The Book of Zechariah in Social Location Trajectory Analysis (Academia Biblica 25; Atlanta: SBL, 2006), 118-23.

25 Sweeney, "Sequence and Interpretation in the Book of the Twelve," 61; Edgar W. Conrad, Zechariah (Sheffield: Sheffield Academic Press, 1999), 42.

26 Nogalski, The Book of the Twelve: Micah-Malachi, 805.

27 Nogalski, The Book of the Twelve: Micah-Malachi, 825. 
8:3). The return of Yahweh to the temple marks a significant turning point as it brings restoration to Zion's reputation. It also makes her a center of splendor and attraction, for the nations. ${ }^{28}$ The hopes that are associated with Yahweh's return are however dashed in Zechariah in 9-14, which push forward the glorious expectations of Jerusalem's status into a remote future subsequent to a time of struggle against nations; an eschatological future in which Yahweh will intervene to put things right (14:1-21). ${ }^{29}$ Although the use of restoration is common in Zechariah 1-8, the eschatological future introduced by Zechariah 9-14 indicates that restoration in Zechariah 1-8 is not final, but that Yahweh will act again in the future. Thus in Zechariah, the struggle for a return (שיוב) and the requirements of Yahweh's actions are in equilibrium. ${ }^{30}$ This equilibrium prepares readers of the Book of the Twelve to further imagine and encounter a positive situation in the book of Malachi regarding the struggle for a return (שוּב), and the experience of Yahweh's actions of blessing His people. Clearly, the foregoing exploration of שוּב in Hosea, Joel, and Zechariah reveals that the call to return (שוּב) is associated with punishment for sins, repentance, and restoration. But in all, the requirements of Yahweh are not satisfactorily met. The following section and sub-sections focus on the struggle for a return (שיוּ) in the book of Malachi.

\section{ASPECTS OF שיוּ IN THE BOOK OF MALACHI}

The book of Malachi is considered as an integrated conclusion and fitting framework for the application of the Book of the Twelve, though with its own unique prophetic outlook. ${ }^{31}$ Written and placed within the background of the return from exile, ${ }^{32}$ Malachi presents an illuminating picture of the unchanging and open-ended unfaithfulness of Yahweh's people in the postexilic Yehudite community. Prior to this time, an overwhelming enthusiasm and optimism has been created by the prediction of preceding prophets concerning the eradication of all Israel/Judah's problems following the return from exile and completion of the temple. However, such positive hope, cheerfulness and confidence were all crushed on the rock of reality. The situation of the people after their return was not different from their portrayal at the beginning of the Book of the Twelve,

28 Anthony R. Petterson, Behold Your King: The Hope for the House of David in the Book of Zechariah (LHBOTS 513; London: T\&T Clark, 2009), 135-137. Nogalski, The Book of the Twelve: Micah-Malachi, 892.

29 LeCureux, The Thematic Unity of the Book of the Twelve, 177.

30 LeCureux, The Thematic Unity of the Book of the Twelve, 179.

31 LeCureux, The Thematic Unity of the Book of the Twelve, 207; Sweeney, "Sequence and Interpretation in the Book of the Twelve," 61-62; John D. W. Watts, "A Frame for the Book of the Twelve: Hosea 1-3 and Malachi," in Reading and Hearing the Book of the Twelve (eds., James D. Nogalski and Marvin A. Sweeney, SBLSS 15; Atlanta: SBL, 2000), 209-218.

32 Lester L. Grabbe, A History of the Jews and Judaism in the Second Temple Period (LSTS 47; New York: T \& T Clark International, 2004), 87. 
where they pay little attention to Yahweh. When Malachi begins, the temple appears to be fully functioning. However, the transgressions, namely false orthodoxy and covenant unfaithfulness that are associated with the Book of the Twelve, continued as component part of daily life of the rebuilt temple. In the light of the re-occurrence of false orthodoxy, cultic malpractices and covenant unfaithfulness, the book of Malachi brings the Book of the Twelve to a close with a call to return through the use of ששוּ 33 The call to return (שיב) is typically associated with the announcement of the expectation of the approaching Day of Yahweh.34 The following sections examine three connected aspects of Malachi's call to return (שוּב): Tשוּב) Torah as a medium of return (שוּב), to the right cult, and Yahweh's return.

\section{Torah as a medium of return (שיבו): Mal 2:6-8}

Malachi's reference to שוֹרבה (Torah) in the second disputation oracle. ${ }^{35}$ Though this is not the first reference to in the book of Malachi, it forms an essential link with the re-emergence of false orthodoxy, cultic malpractices and covenant unfaithfulness that is noticeable in the Book of the Twelve. Having constructed and presented a coherent apology for Yahweh's fidelity to His covenant and sovereignty over history in the first oracle unit (1:15), Malachi's second oracle (1:6-2:9) ends with a harsh indictment of his contemporaries (2:6-9), who in contrast to Levi, have failed to live up to the standard expected of them. The priests are criticised for their disrespect for

33 There are seven occurrences of the word in Malachi $(1: 4 ; 2: 6 ; 3: 7[3 x], 18$, and 24 [4:6 ET]) with an imperative use in 3:7. See Andrew E. Hill, Malachi: A New Translation with Introduction and Commentary (AB 24D; New York: Doubleday, 1998), 344.

34 Michael U. Udoekpo, Re-Thinking the Day of YHWH and the Restoration of Fortunes in the Prophet Zephaniah: An Exegetical and Theological Study of 1:14-18; 3:14-20 (Bern: Peter Lang AG, 2010), 228; Geerhardus Vos, The Eschatology of the Old Testament (New Jersey: P\&R Publishing Company, 2001), 601-602.

35 The second disputation (1:6-2:9), described as the longest, is directed at Malachi's contemporary ministry colleagues - the priests. Here, Yahweh is cast as the subject in the first part of the two separate speech-acts (1:6-14) and Malachi's ministry colleagues as the subject of the second part (2:1-9). See Eileen M. Schuller, "The Book of Malachi," in The New Interpreter's Bible, Vol. 6 (ed., Leander E. Keck; Nashville: Abingdon Press, 1996), 843-877 (858); Hill, Malachi, 172-173; Mark J. Boda, "Perspectives on Priest in Haggai-Malachi," in Prayer and Poetry in the Dead Sea Scrolls and Related Literature: Essays in honor of Eileen Schuller on the occasion of her 65th birthday (eds., Jeremy Penner, Ken M. Penner and Cecilia Wassen; STDJ 98; Brill: Leiden, 2012), 13-33 (15). 
Yahweh in cultic matters $(1: 6-2: 3)$ and for constituting a barrier to the genuine return of the people to Yahweh through their priestly instruction $(2: 8) .{ }^{36}$

On the one hand, there is a presentation of a positive return (שיוּ) through Levi. ${ }^{37}$ Malachi describes Levi as rightfully discharging (by way of correct

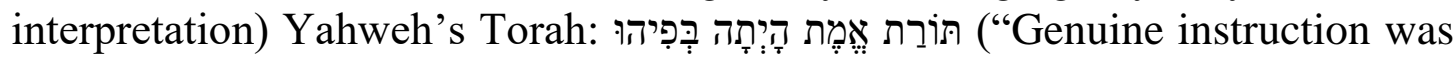

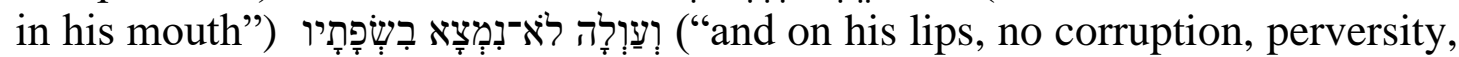
iniquity was found"). He was consistently committed in various ministerial

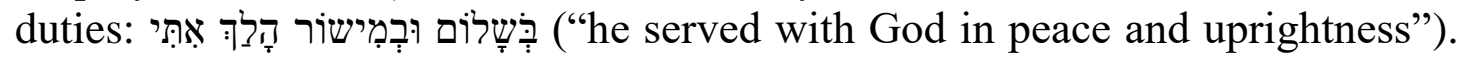
Because there was no contrast between Levi's life and his ministerial responsibilities, "he turned many away from iniquity," namely what was wrong

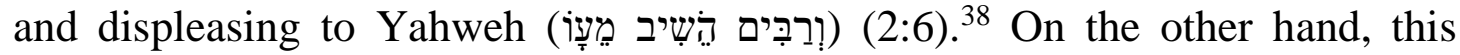
portrayal of Yahweh's Torah as a vehicle for successful return (שיבר) is noticeably absent in the book of Malachi. Malachi's ministry colleagues rather than embodying this portrait of an ideal priest (2:6-7) lived in blatant disobedience, manifested in their failure in life and ministry $(2: 8)$. The resultant implication was that, rather than using (שוֹרבי (שיבה), they a made many to turn away from Yahweh and stumble into sin by neglecting their priestly responsibility of תiأרָ instruction. ${ }^{39}$ Thus in Malachi, because of the collective failure of contemporary priests both in life and ministry, a successful return (שיח)

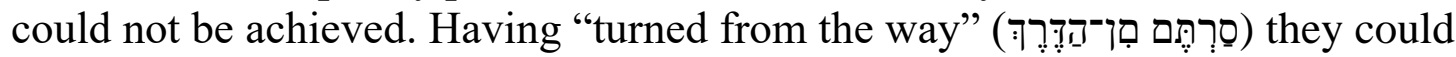

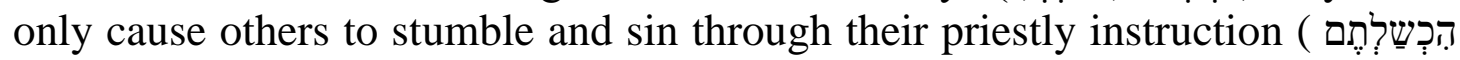

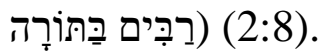

\section{Return (שיו) to the right cult: Mal 3:7}

In the book of Malachi, the pragmatic text that embodies the use of return (שיב) in the imperative is found in the fifth oracle unit $(3: 6-12){ }^{40}$ This unit focuses on

36 Lena-Sofia Tiemeyer, Priestly Rites and Prophetic Rage: Post-exilic Prophetic Critique of the Priesthood (FAT 2/19; Tubingen: Mohr Siebeck, 2006), 18.

37 There are various scholarly debates regarding the distinction between priests and Levites. The suggestion is given that the priests are to be addressed from the point of view of the covenant with Levi (Deut 33:8-11), with the reference to Levi (2:5f) as proLevitical and anti-priestly. See Rex A. Mason, Preaching the Tradition: Homily and Hermeneutics after the Exile (Cambridge: Cambridge University, 1990), 244; Redditt, Haggai, Zechariah and Malachi, 151f; Petersen, Zechariah 9-14 and Malachi, 191193. In all probability, the distinction here is between an ideal priest embodied as Levi and Malachi's contemporary ministry colleagues. Tiemeyer, Priestly Rites and Prophetic Rage, 127.

38 Julia M. O'Brien, Priest and Levite in Malachi (SBLDS 121; Atlanta: Scholars Press, 1990), 42; Tiemeyer, Priestly Rites and Prophetic Rage: Post-exilic Prophetic Critique of the Priesthood, 131.

39 O'Brien, Priest and Levite in Malachi, 35-36.

40 In several structural analyses of Malachi, scholars consider Mal 3:7 as part of the Malachi's $5^{\text {th }}$ oracle unit. See Hill, Malachi, 26; Julia M. O'Brien, Nahum, Habakkuk, 
the infertility of the land and how to change the situation. Dissatisfaction with the manner in which the cult is being managed constitutes several materials in the book of Malachi. Both the priests and people are confronted regarding the magnitude to which their material offerings, both in terms of quantity and quality, reflect violation of covenantal requirements $(1: 6-10,13-14 ; 2: 1-9)$. This covenantal violation proved Yahweh's curse upon them and their blessings:

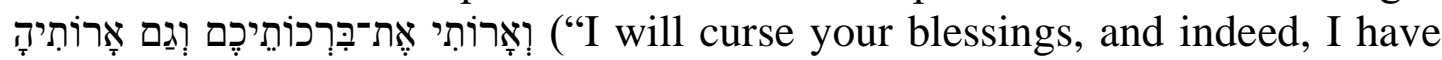
cursed them," 2:2). Thּרכוֹתֵיכֶם ("your blessings") in 2:2 is variously construed. O'Brien holds that it could either be the priestly blessings upon the people or the material agricultural produce which the people give to the priests as tithes (Num 18:21). ${ }^{41}$ However, in light of the current situation (cf. 3:6-12) in which both the priests and people are held responsible, infertility of the land could be a fitting explanation as it affects both parties. ${ }^{42}$

Malachi presumes that the land's infertility is a manifestation of Yahweh's curse (2:2), a curse that appears to be ongoing and which will become more acute. ${ }^{43}$ Consequently, the imperative exhortation to return to Yahweh: שִּוּבוּ אִבי וְזָשוּרָה אָלִיכֶם ("Return to me and I will return to you"), functions as part of the fundamental logic of 3:6-12, a unit that is appropriated to challenge the people with a call to repent and return to Yahweh. Regarding the persuasive significance of the assertive speech act of this unit, Hill remarks that it serves to reinvigorate and stimulate the postexilic Yehudite community, by accentuating Yahweh's changelessness, and opposing the people's charges of unreliability and impulsiveness on Yahweh's part. Consequently, Malachi uses this point to deal with various aspects that are related to both human and community experience, in coping with deferred hope, shattered dreams, and unrealised promises. ${ }^{44}$

After a defense of Yahweh's faithfulness and unchangeableness which many skeptics have questioned (3:6; cf. 1:2-5), ${ }^{45}$ Malachi continues with his characteristic description of Israel/Judah's historical past and present as that of

Zephaniah, Haggai, Zechariah, Malachi (AOTC; Nashville: Abingdon Press, 2004), 286; E. Ray Clendenen, "Malachi," in Haggai, Malachi (eds., Richard A. Taylor and E. Ray Clendenen, NAC 21A; Nashville: Broadman and Holman Publishers, 2004), 203-464 (227). Others place it in the $4^{\text {th }}$ disputation (2:17-3:6). See David J. Clark and Howard A. Hatton, A Handbook on Haggai, Zechariah and Malachi (New York: United Bible Societies, 2002), 370; David A. Dorsey, The Literary Structure of the Old Testament: A Commentary on Genesis to Malachi (Grand Rapids: Baker Book House, 1999), 323.

41 O'Brien, Priest and Levite in Malachi, 32.

42 The substance of the indictment in 3:6-12 is believed to include both the priest and people. Tiemeyer, Priestly Rites and Prophetic Rage, 26-27; Beth Glazier-McDonald, Malachi: The Divine Messenger (SBLDS 98; Atlanta: Scholars Press, 1987), 67-68.

43 Nogalski, The Book of the Twelve: Micah-Malachi, 1004.

44 Hill, Malachi, 294.

45 Schuller, "The Book of Malachi," 870. 
unfaithfulness, apostasy and rebellion (3:7). ${ }^{46}$ The accusation reaches its climax

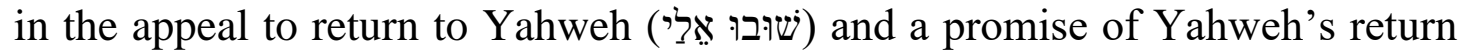

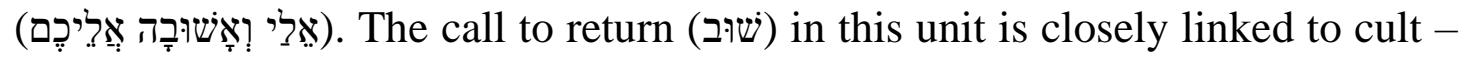
tithe (3:7), and the fulfillment of it depends on the obedience of the people. The current situation is described by Malachi as the function of a covenant curse provoked by widespread corruption of both the people and priests, who have failed in the performance of their covenantal responsibilities $(3: 8-9)$. One of the important deductions that one can make of the text is that, even in unfavourable conditions as they were, as a matter of cultic covenant requirement, the people were encouraged to unreservedly bring their tithes $(3: 10)$.

The climax of this unit's motif $(3: 8-11)$ indicates that the people's positive submission and response will result in their experience of Yahweh's return with abundant blessings. ${ }^{47}$ The release of rain to water their crops, as well as the removal of the "locusts" that have ravaged the land and its produce, indicate that the people have experienced a want of it, and in some respect, a manifestation of a covenant curse (Deut 28:22-24; cf. Lev 26:19). ${ }^{48}$ Accordingly, the "devourer" in 3:11 serves as a metaphor of both sterility and military invasion. These have a substantial impact on the capacity of the land to feed its people. The logic behind the testing introduced in 3:10 reveals that the fertility of the land, namely its failure to produce enough crops to sustain the people, is indeed a failure that only a return (שווב) to Yahweh through the medium of fulfillment of all cultic aspects and Torah-keeping of His covenant will change, and in the positive direction. ${ }^{49}$ If people desire Yahweh's blessings and want to remedy the present dilemma, they must demonstrate their readiness to return (שוּב) to Yahweh through the medium of the cult - they must give their tithes without reservation. Such unreserved dedication of service will provoke Yahweh's return with immediate restorative blessings.

\section{Yahweh's return (שטוּ): Mal 3:24 (ET 4:6)}

Like the rest of the Book of the Twelve, Malachi's use of return (שיוּ) in 3:24 (ET 4:6) is intimately linked with the characteristic Day of Yahweh, and this is found in the book's epilogue (MT 3:22-24, ET 4:4-6). ${ }^{50}$ Despite the existence

46 Karl W. Weyde, Prophecy and Teaching: Prophetic Authority, Form Problems, and the Use of Traditions in the Book of Malachi (BZAW 288; Berlin: Walter de Gruyder 2000), 328.

47 Clendenen, "Malachi," 425.

48 Douglas Stuart, "Malachi," in The Minor Prophets: An Exegetical and Expository Commentary, Vol. 3 (ed., Thomas E. McComiskey; Grand Rapids: Baker Books, 1998), 1371.

49 Nogalski, The Book of the Twelve: Micah-Malachi, 1004.

50 For redactional and literary discussions regarding Malachi's epilogue, see Michael H. Floyd, Minor Prophets (Grand Rapids: Eerdmans / Baker Books, 2000), 625; Elie Assis, "Moses, Elijah and the Messianic Hope: A New Reading of Malachi 3:22-24," 
of several possibilities of interpretation, in both thematic and linguistic respects, Malachi 3:22-24 is related to the previous oracles and fits very well Malachi's context and conclusion of the prophecy with a secondary canonical function, namely the ending of the Book of the Twelve in both the MT and LXX. ${ }^{51}$ This text is set against the background of the problem of evil and the prosperity of evildoers that have led the faithful remnants in Malachi's postexilic Yehudite community to question their continued commitment to Yahweh. From their experience and perspective, the reality of injustice and Yahweh's inattentiveness gave room to resentment, regret and anger. Their theological summation was that Yahweh's rule was inconsistent with the principle of justice. ${ }^{52}$ Malachi thus uses the idea of return (שיוּ) to interject hope into a miserable and depressed situation in the postexilic Yehudite community. Malachi begins his final exhortation by calling attention to Israel's historic past and then focuses on an imminent future of restoration and reversal of fortunes. He pointedly situates the ethical impact of the prophecy in the dual categories of Israel's eschatological hopes and redemption (the ultimate experience of justice and peace). ${ }^{53}$

The motif of return (שיב) is associated with the Day of Yahweh that manifests several literary traits in the book of Malachi $(3: 24)$. Though the identity of the eschatological covenant messenger of 3:1 is unclear, ${ }^{54}$ the specific assignments are obvious. In 3:1-5, Malachi speaks of the imminent and dreadful arrival of an eschatological covenant messenger, whose essential duties are cult revitalisation (purification of the priests and restoration of acceptable worship,

ZAW 123/2 (2011): 208-209, https://doi.org/10.1515/zaw.2011.013; Russell Fuller, "The sequence of Malachi 3:22-24 in the Greek and Hebrew textual Traditions: Implications for the Redactional History of the Minor Prophets," in Perspectives of the Formation of the Book of the Twelve (eds., Rainer Albertz, James D. Nogalski and Jacob Wohrle; Berlin, MA.: Walter de Gruyter, 2012), 371-379 (272-273).

51 Glazier-McDonald, Malachi the Divine Messenger, 267; Barry A. Jones, The Formation of the Book of the Twelve: A Study in Text and Canon (SBLDS 149; Atlanta: Scholars Press, 1995), 236-237; Watts, "A Frame for the Book of the Twelve: Hosea 1-3 and Malachi," 209-211; Stephen B. Chapman, "A canonical Approach to Old Testament Theology? Deuteronomy 34:10-12 and Malachi 3:22-24 as Programmatic Conclusion," HBT 25/1 (2003): 139, http://dx.doi.org/10.1163/187122003X00105.

52 Petersen, Zechariah 9-14 and Malachi, 221; Assis, "Structure and Meaning in the Book of Malachi," 365-366.

53 Clendenen, "Malachi," 454-455; John Barton, Oracles of God: Perceptions of Ancient Prophecy in Israel after the Exile (New York: Oxford, 1986), 16.

54 Several scholarly debates have been made regarding the identity of Malachi's covenant messenger with different proposals leading the discussion. For details see, Bruce V. Malchow, “The Messenger of the Covenant in Malachi 3," JBL 103 (1984): 252-255; Stephanus D. Snyman, "Once Again: Investigating the Identity of the Three Figures Mentioned in Malachi 3:1," VetE 27/3 (2006):1031-1044; David M. Miller, "The Messenger, the Lord, and the Coming Judgment in the Reception History of Malachi 3," NTS 53/1 (2007):1-16. 
$3: 2 b-4),{ }^{55}$ and enforcement of justice against those community members who have violated covenant requirements (3:5). The purpose of this enforcement of justice will be the restoration, and reversal of the fortune of those faithful survivors of the exile as well as punishment and complete destruction of evildoers $(3: 16-21) .{ }^{56}$

Malachi 3:22-24 (ET 4:4-6), however, introduces the coming of Elijah (as the messenger, 3:23) ${ }^{57}$ who after the interval of instruction in Moses' Torah of the faithful (3:22, ET 4:4), will turn (וְٕהשיב) the hearts of the fathers to the

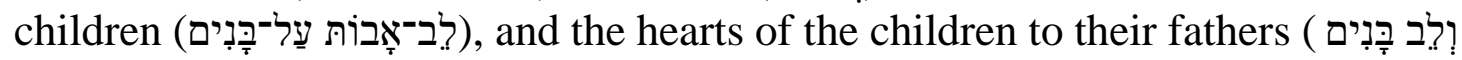

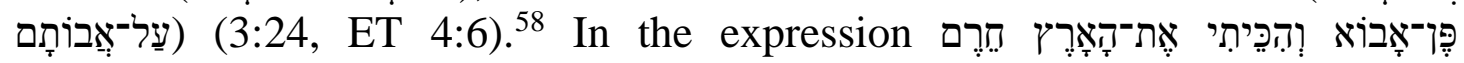
("otherwise I come to utterly smite the land with a curse"), the conjunctive

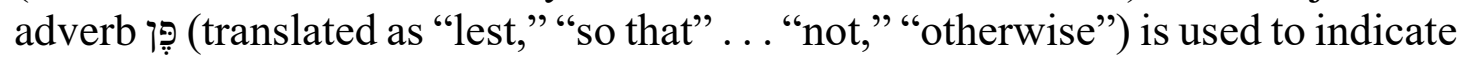
the prevention of a theoretically possible event (cf. Gen 3:22) or prevention of an otherwise predictable event (cf. Gen 19:19; 26:7-9). In this regard, Elijah's mission could be described as that of reconciling families and community members with one another with the ultimate intention of preventing or holding back Yahweh's anger against the entire population, both young and old. ${ }^{59}$ This particular understanding of Malachi's use of return (שיוּ) to describe families' reconciliation and community restoration, and its association with obedience to Yahweh's covenant requirements, establishes once again the exhortational character of Malachi's oracle. The rhetorical goal of Malachi goes beyond that of encouraging the people and priests to remembering Yahweh's Torah. It includes an attempt to persuade them to actively apply Yahweh's Torah, as a united community, in a manner that will resolve the conflict that has disorganised and divided its members. ${ }^{60}$ The success of Elijah's mission is thus critical to the continued existence of the postexilic Yehudite community.

\footnotetext{
55 O'Brien, Priest and Levite in Malachi, 74.

56 Nogalski, The Book of the Twelve: Micah-Malachi, 1065.

57 For those who support the view that Elijah is the eschatological messenger, see Walter C. Kaiser Jr., Malachi - God's Unchanging Love (Grand Rapids: Baker Book House,1986), 80; Pieter A. Verhoef, The Books of Haggai and Malachi (NICOT; Grand Rapids: Eerdmans,1987), 340.

58 The LXX reading indicates that Elijah's mission will not only be that of turning the hearts of the fathers to the children but also turning the hearts of the people to their neighbours.

59 Nogalski, The Book of the Twelve: Micah-Malachi, 1005; Markus Öhler, "The Expectation of Elijah and the Presence of the Kingdom of God," JBL 118/3 (1999): 461-462.

60 Marvin A. Sweeney, The Twelve Prophets: Micah Nahum, Zephaniah, Haggai, Zechariah, Malachi (Collegeville, MN: The Liturgical Press, 2001), 749-750.
} 


\section{SYNTHESIS AND CONCLUSION}

This article's aim was to examine the motif of return (שוּב) in Malachi against the background of the call to return (שיב) in the Book of the Twelve. The focal points of שישוב in the mosea, Joel and Zechariah were explored. As observed, appears in three broad categories of punishment, restoration and repentance. As interpreters of past and present difficulties, these prophets are seen as Yahweh's messengers, instructing especially the postexilic Yehudite community on how to avoid the mistakes that led to the exile and to flourish. Postexilic Yehudite community, like others of the present day, evidently struggled with disappointment in its initial efforts to rebuild, especially in light of extravagant promises of prosperity given in exilic-period prophecies. One obvious answer to such struggles was a reinterpretation of the words of past prophets to see how they needed to return/repent (שיב) in ways that would revitalise the community in postexilic Yehud ${ }^{61}$ Therefore, it is well acknowledged that Malachi creatively reinterpreted this theme from a canonical context for the readers. ${ }^{62}$

The struggle for a successful return (שיוּ) is noticeably prevalent in the Book of the Twelve and as the book of Malachi has consistently shown, remains unheeded by the people, thus creating the prospect of a covenant curse. However, Malachi's exhortation to return (שיב) through the media of cult and Torah in connection with Yahweh's return provides enough motivation and stability for the present and future generation to keep their land (community) from being cursed. The call to return (שיוּ) brings together covenantal requirements (of the right cult and Torah-keeping) in view of the anticipated arrival of the Day of Yahweh. The combination of cultic aspects and Torahkeeping with eschatological hope permeates Malachi's prophecy with an effective and persuasive reminder of the significance of the Law and Prophets (represented by the biblical figures of Moses and Elijah), for the believing faith community. However, the difficulty of negotiating reconciliation between Malachi's call to return (שיוּ) and the idea of an approaching Day of Yahweh, creates an enigma not only for readers of the Book of Twelve, but also a paradox for interpreters of New Testament eschatology. Such polarisation stimulates readers not only to hear the necessity of living in the light of the nearness of the Day of Yahweh, but also to study and live in loyal obedience as the Day of Yahweh may come in the near future. ${ }^{63}$

The exhortation to return (שיוּ) through the media of cult and Torah, serves to ground the present community - those survivors of the exile who hope to endure the Day of Yahweh - in the traditions of the past and to guide her into a prosperous

61 David M. Carr, The Formation of the Hebrew Bible: A New Reconstruction (Oxford: Oxford University Press, 2011), 223.

62 Sweeney, "Sequence and Interpretation," 62.

63 Nogalski, The Book of the Twelve: Micah-Malachi, 1005. 
future. Accordingly, Yahweh's return stimulates critical reflection and compliance with conditions of covenantal relationship with Yahweh, one that includes all cultic aspects and Torah-keeping of His covenant and hope for reconciliation between parents and children so that the traditions might successfully pass from one generation to the other. Thus, the prophecy presents a perspective that transcends sociopolitical entities. Although it is not easy to envisage a positive return to Yahweh, there is profoundly an apparent persuasive theological message associated with the call to return. The call conveys the idea of reciprocal relationship in which both Yahweh and His people have a commitment to make for its realisation. The most profound element of the motif of return (שוּב) is the circle of relationship that requires faithful and relentless development.

\section{BIBLIOGRAPHY}

Assis, Elie. "Structure and Meaning in the Book of Malachi." Pages 354-369 in Prophecy and the Prophets in Ancient Israel: Proceedings of the Oxford Old Testament Seminar. Edited by John Day. Library of Hebrew Bible/Old Testament Studies 531. New York: T \& T Clark, 2010.

. "Moses, Elijah and the Messianic Hope: A New Reading of Malachi 3:22-

24." Zeitschrift fur die Alttestamentliche Wissenschaft 123/2 (2011): 207-220. https://doi.org/10.1515/zaw.2011.013.

Barton, John. Oracles of God: Perceptions of Ancient Prophecy in Israel after the Exile. New York: Oxford, 1986.

Boda, Mark J. "From Fasts to Feasts: The Literary Function of Zechariah 7-8." Catholic Biblical Quarterly 65 (2003): 390-407.

. "Perspectives on Priest in Haggai-Malachi." Pages 13-33 in Prayer and Poetry in the Dead Sea Scrolls and Related Literature: Essays in honor of Eileen Schuller on the occasion of her 65th birthday. Edited by Jeremy Penner, Ken M. Penner and Cecilia Wassen. Studies on the Texts of Desert of Judah 98; Brill: Leiden, 2012.

Carr, David M. The Formation of the Hebrew Bible: A New Reconstruction. Oxford: Oxford University Press, 2011. https://doi.org/10.1093/acprof:oso/9780199742 608.001.0001.

Chapman, Stephen B. "A canonical Approach to Old Testament Theology? Deuteronomy 34:10-12 and Malachi 3:22-24 as Programmatic Conclusion." Horizons in Biblical Theology 25/1 (2003):121-145. http://dx.doi.org/10.1163/ $187122003 X 00105$.

Chisholm, Robert B. Jr. Interpreting the Minor Prophets. Grand Rapids: Zondervan, 1990.

Clark, David J. and Hatton, Howard A. A Handbook on Haggai, Zechariah and Malachi. New York: United Bible Societies, 2002.

Clendenen, E. Ray. "Malachi." Pages 203-464 in Haggai, Malachi. Edited by Richard A. Taylor and E. Ray Clendenen. New American Commentary 21A; Nashville: Broadman and Holman Publishers, 2004.

Collins, Terence. "The Scroll of the Twelve." The Mantle of Elijah: The Redaction Criticism of the Prophetic Books. The Biblical Seminar 20. Sheffield; Sheffield Academic Press, 1993. 
Conrad, Edgar W. Zechariah. Sheffield: Sheffield Academic Press, 1999.

Curtis, Byron G. Up the Steep and Stony Road: The Book of Zechariah in Social Location Trajectory Analysis. Academia Biblica 25. Atlanta: Society of Biblical Literature, 2006.

Dorsey, David A. The Literary Structure of the Old Testament: A Commentary on Genesis to Malachi. Grand Rapids: Baker Book House, 1999.

Floyd, Michael H. Minor Prophets. Grand Rapids: Eerdmans / Baker Books, 2000.

Fox, R. Michael. A Message from the Great King: Reading Malachi in Light of Ancient Persian Royal Messenger Texts from the Time of Xerxes. Literature and Theology of the Hebrew Scriptures 17. Winona Lake: Eisenbrauns, 2015.

Frolov, Serge. "Is the Narrator also Among the Prophets? Reading Zechariah without Presuppositions." Biblical Interpretation 13 (2005): 13-40. https://doi.org/ $10.1163 / 1568515053279166$.

Fuller, Russell. "The sequence of Malachi 3:22-24 in the Greek and Hebrew textual Traditions: Implications for the Redactional History of the Minor Prophets." Pages 371-379 in Perspectives of the Formation of the Book of the Twelve. Edited by Rainer Albertz, James D. Nogalski and Jacob Wohrle. Berlin, MA.: Walter de Gruyter, 2012.

Garrett, Duane A. Hosea, Joel: New American Commentary. Nashville: Broadman \& Holman, 1997.

Glazier-McDonald, Beth. Malachi: The Divine Messenger. Society of Biblical Literature Dissertation Series 98. Atlanta: Scholars Press, 1987.

Grabbe, Lester L. A History of the Jews and Judaism in the Second Temple Period. Library of Second Temple Studies 47. New York: T \& T Clark International, 2004.

Hill, Andrew E. Malachi: A New Translation with Introduction and Commentary. Anchor Bible 24D. New York: Doubleday, 1998.

Hoerth, Alfred J. Archaeology and the Old Testament. Grand Rapids: Baker, 1998.

House, Paul R. The Unity of the Twelve. JSOT Supplement Series 97. Sheffield: Sheffield Academic Press 1990.

Johnson, Rick. "Hosea 4-10: Pictures at an Exhibition." Southwestern Journal of Theology 36 (1993): 20-26.

Jones, Barry A. The Formation of the Book of the Twelve: A Study in Text and Canon Society of Biblical Literature Dissertation Series 149. Atlanta: Scholars Press, 1995.

Kaiser, Walter C. Jr. Malachi - God's Unchanging Love. Grand Rapids: Baker Book House, 1986.

. A History of Israel. Nashville, Broadman \& Holman, 1998.

Keil, Carl Friedrich and Delitzsch, Franz. The Minor Prophets, vol. 2. Translated by James Martin. Grand Rapids: Eerdmans, 1949.

Landy, Francis. "In the Wilderness of Speech: Problems of Metaphor in Hosea." Biblical Interpretation 3 (1995): 35-39. https://doi.org/10.1163/156851595X000 32.

LeCureux, Jason T. The Thematic Unity of the Book of the Twelve. Hebrew Bible Monograph 41. Sheffield: Sheffield Phoenix Press, 2012.

Malchow, Bruce V. "The Messenger of the Covenant in Malachi 3." Journal of Biblical Literature 103 (1984): 252-255. https://doi.org/10.2307/3260273. 
160 Boloje, "Returning to Yahweh," OTE 33/1 (2020): 143 - 161

Mason, Rex A. Preaching the Tradition: Homily and Hermeneutics after the Exile. Cambridge: Cambridge University, 1990. https://doi.org/10.1017/CBO9780511 470462.

Miller, David M. "The Messenger, the Lord, and the Coming Judgment in the Reception History of Malachi 3." New Testament Studies 53/1 (2007): 1-16. https://doi.org /10.1017/S002868850700001X.

Nogalski, James D. "Recurring Themes in the Book of the Twelve: Creating Points of Contact for a Theological Reading." Interpretation 61 (2007): 125-136. https://doi.org/10.1177/002096430706100202.

. The Book of the Twelve: Micah-Malachi. Macon, Georgia: Smyth \& Helwys Publishing, Inc., 2011.

O’Brien, Julia M. Priest and Levite in Malachi. Society of Biblical Literature Dissertation Series 121. Atlanta: Scholars Press, 1990.

. Nahum, Habakkuk, Zephaniah, Haggai, Zechariah, Malachi. Abingdon Old Testament Commentary. Nashville: Abingdon Press, 2004.

Öhler, Markus. "The Expectation of Elijah and the Presence of the Kingdom of God." Journal of Biblical Literature 118/3 (1999): 461-476. https://doi.org/10.2307 13268184.

Petersen, David L. Zechariah 9-14 and Malachi. Louisville: Westminster John Knox, 1995.

Petterson, Anthony R. Behold Your King: The Hope for the House of David in the Book of Zechariah. Library of Hebrew Bible/Old Testament Studies 513. London: T\&T Clark, 2009.

Redditt, Paul L. "Nehemiah's First Mission and the Date of Zechariah 9-14." Catholic Biblical Quarterly 56 (1994): 664-678.

Haggai, Zechariah and Malachi. New Century Bible Commentary. Grand Rapids: Eerdmans: 1995.

. "The Production and Reading of the Book of the Twelve." Pages 11-33 in Reading and Hearing the Book of the Twelve. Edited by James D. Nogalski and Marvin A. Sweeney. Society of Biblical Literature Symposium Series 15. Atlanta: Society of Biblical Literature, 2000.

. "Themes in Haggai-Zechariah-Malachi." Interpretation 61 (2007): 184-197. https://doi.org/10.1177/002096430706100206.

Schuller, Eileen M. "The Book of Malachi." Pages 843-877 in The New Interpreter's Bible, Vol. 6. Edited by Leander E. Keck. Nashville: Abingdon Press, 1996.

Smith, John Merlin. A Critical and Exegetical Commentary on the Book of Malachi. New York: T \&T Clark, 1912.

Snyman, Stephanus D. "Once Again: Investigating the Identity of the Three Figures Mentioned in Malachi 3:1." Verbum et Ecclesia 27/3 (2006):1031-1044. https://doi.org/10.4102/ve.v27i3.202.

Stuart, Douglas. "Malachi." Pages 1245-1396 in The Minor Prophets: An Exegetical and Expository Commentary, Vol. 3. Edited by Thomas E. McComiskey. Grand Rapids: Baker Books, 1998.

Sweeney, Marvin A. "Sequence and Interpretation in the Book of the Twelve." Pages 4964 in Reading and Hearing the Book of the Twelve. Edited by James D. Nogalski and Marvin A. Sweeney. Society of Biblical Literature Symposium Series 15. Atlanta: Society of Biblical Literature, 2000. 
. The Twelve Prophets: Micah Nahum, Zephaniah, Haggai, Zechariah, Malachi. Collegeville, MN: The Liturgical Press, 2001.

. "Synchronic and Diachronic Concerns in Reading the Book of the Twelve Prophets." Pages 21-33 in Perspectives on the Formation of the Book of the Twelve. Edited by Albertz, Rainer, Nogalski, James D. and Wöhrle, Jakob. Beihefte zur Zeitschrift für die alttestamentliche Wissenschaft 433. New York: Walter de Gruyter, 2012.

Tiemeyer, Lena-Sofia. Priestly Rites and Prophetic Rage: Post-exilic Prophetic Critique of the Priesthood. Forschungen zum Alten Testament 2/19. Tubingen: Mohr Siebeck, 2006.

Timmer, Daniel C. The Non-Israelite Nations in the Book of the Twelve: Thematic Coherence and the Diachronic-Synchronic Relationship in the Minor Prophets. Biblical Interpretation Series 135. Leiden: Brill 2015.

Udoekpo, Michael U. Re-Thinking the Day of YHWH and the Restoration of Fortunes in the Prophet Zephaniah: An Exegetical and Theological Study of 1:14-18; 3:14-20. Bern: Peter Lang AG, 2010.

VanGemeren, Willem A. Interpreting the Prophetic Word. Grand Rapids: Zondervan, 1990.

Verhoef, Pieter A. The Books of Haggai and Malachi. The New International Commentary on the Old Testament. Grand Rapids: Eerdmans, 1987.

Vos, Geerhardus. The Eschatology of the Old Testament. New Jersey: P \& R Publishing Company, 2001.

Watts, John D. W. "A Frame for the Book of the Twelve: Hosea 1-3 and Malachi." Pages 209-218 in Reading and Hearing the Book of the Twelve. Edited by James D. Nogalski and Marvin A. Sweeney. Society of Biblical Literature Symposium Series 15. Atlanta: Society of Biblical Literature, 2000.

Weyde, Karl W. Prophecy and Teaching: Prophetic Authority, Form Problems, and the Use of Traditions in the Book of Malachi. Beihefte zur Zeitschrift für die alttestamentliche Wissenschaft 288. Berlin: Walter de Gruyder 2000. https://doi. org/10.1515/9783110811780.

Wöhrle, Jacob. "The Formation and Intention of the Haggai-Zechariah Corpus." Journal of Hebrew Scriptures 6/10 (2006): 1-14. https://doi.org/10.5508/jhs. 2006.v6.a10.

Blessing Onoriode Boloje is a lecturer at the Baptist Theological Seminary, EkuNigeria; Research Fellow of the Alexander von Humboldt Foundation, RuhrUniversität Bochum, Germany; and Research Associate, Department of Old Testament and Hebrew Scriptures, Faculty of Theology and Religion, University of Pretoria, South Africa. Email: pstbobson@yahoo.co.uk ORCID: https://orcid.org/0000-0002-7480-3805. 